\title{
Date Palm Extract (Phoenix dactylifera) PEGylated Nanoemulsion: Development, Optimization and Cytotoxicity Evaluation
}

\author{
Hany Ezzat Khali1 1,2,*, Nashi K. Alqahtani ${ }^{3}$, Hossam M. Darrag 4,5 , Hairul-Islam Mohamed Ibrahim 6 (D), \\ Promise M. Emeka ${ }^{1}{ }^{\mathbb{D}}$, Lorina I. Badger-Emeka ${ }^{7} \mathbb{D}$, Katsuyoshi Matsunami ${ }^{8} \mathbb{D}$, Tamer M. Shehata ${ }^{1,9}$ \\ and Heba S. Elsewedy ${ }^{1}$ D
}

check for updates

Citation: Khalil, H.E.; Alqahtani, N.K.; Darrag, H.M.; Ibrahim, H.-I.M.; Emeka, P.M.; Badger-Emeka, L.I.; Matsunami, K.; Shehata, T.M.; Elsewedy, H.S. Date Palm Extract (Phoenix dactylifera) PEGylated Nanoemulsion: Development, Optimization and Cytotoxicity Evaluation. Plants 2021, 10, 735. https://doi.org/10.3390/plants 10040735

Academic Editor:

Konstantinos Gardikis

Received: 19 March 2021

Accepted: 6 April 2021

Published: 9 April 2021

Publisher's Note: MDPI stays neutral with regard to jurisdictional claims in published maps and institutional affiliations.

Copyright: (c) 2021 by the authors. Licensee MDPI, Basel, Switzerland. This article is an open access article distributed under the terms and conditions of the Creative Commons Attribution (CC BY) license (https:/ / creativecommons.org/licenses/by/ $4.0 /)$.
1 Department of Pharmaceutical Sciences, College of Clinical Pharmacy, King Faisal University, Al-Ahsa 31982, Saudi Arabia; pemeka@kfu.edu.sa (P.M.E.); tshehata@kfu.edu.sa (T.M.S.); helsewedy@kfu.edu.sa (H.S.E.)

2 Department of Pharmacognosy, Faculty of Pharmacy, Minia University, Minia 61519, Egypt

3 Department of Food Science and technology, College of Agriculture, King Faisal University, Al-Ahsa 31982, Saudi Arabia; nalqahtani@kfu.edu.sa

4 Research and Training Station, King Faisal University King Faisal University, Al-Ahsa 31982, Saudi Arabia; hdarag@kfu.edu.sa

5 Pesticide Chemistry and Technology Department, Faculty of Agriculture, Alexandria University, El-Shatby 21545, Egypt

6 Biological Sciences Department, College of Science, King Faisal University, Al-Ahsa 31982, Saudi Arabia; himohamed@kfu.edu.sa

7 Department of Biomedical Sciences, College of Medicine, King Faisal University, Al-Ahsa 31982, Saudi Arabia; lbadgeremeka@kfu.edu.sa

8 Department of Pharmacognosy, Graduate School of Biomedical \& Health Sciences, Hiroshima University, 1-2-3 Kasumi, Minami-ku, Hiroshima 734-8553, Japan; matunami@hiroshima-u.ac.jp

9 Department of Pharmaceutics, College of Pharmacy, Zagazig University, Zagazig 44519, Egypt

* Correspondence: heahmed@kfu.edu.sa

Abstract: Date palm fruit (Phoenix dactylifera) is reputed to have numerous biological activities, including anticancer properties. To utilize the great fortune of this fruit, the current study aimed to maximize its pharmacological activity. Date palm extract (DPE) of Khalas cultivar was obtained in powder form and then was formulated into nanoemulsion (NE). The optimized DPE-NE was formulated along with its naked counterpart followed by studying their physical and chemical properties. A qualitative assessment of total serum protein associated with the surface of formulations was implemented. Studies for the in vitro release of DPE from developed NE before and after incubation with serum were investigated. Eventually, an MTT assay was conducted. Total phenolic and flavonoid contents were $22.89 \pm 0.013 \mathrm{mg} \mathrm{GAE} / \mathrm{g}$ of dry DPE and $9.90 \pm 0.03 \mathrm{mg} \mathrm{QE} / \mathrm{g}$ of dry DPE, respectively. Homogenous NE formulations were attained with appropriate particle size and viscosity that could be administered intravenously. The optimized PEGylated NE exhibited a proper particle size, PDI, and zeta potential. Total serum protein adsorbed on PEG-NE surface was significantly low. The release of the drug through in vitro study was effectively extended for $24 \mathrm{~h}$. Ultimately; PEGylated NE of DPE attained significant inhibition for cancer cell viability with IC $_{50}$ values of $18.6 \pm 2.4$ and $13.5 \pm 1.8 \mu \mathrm{g} / \mathrm{mL}$ for MCF-7 and HepG2 cell lines, respectively. PEGylated NE of DPE of Khalas cultivar will open the gate for future adjuvants for cancer therapy.

Keywords: phoenix dactylifera; nanoemulsion; date palm extract; optimization; cytotoxicity

\section{Introduction}

As a fact, nature provides us with great reservoirs of plants as potential therapeutic candidates. Currently, the consumption of fruits and vegetables is considered important and beneficial for the health conditions to reduce the risk of several diseases such as 
cardiovascular disorders, aging, atherosclerosis, neurodegenerative conditions, and cancer. The valuable protective and curative activities are attributed in particular to their high dietary antioxidant contents, which can protect the human body against various oxidative reactions [1,2]. One of the most famous types of edible fruit is date fruit. Date fruits are cheap and rich source of carbohydrates, proteins, amino acids, and essential minerals (zinc, copper, selenium, potassium, calcium, magnesium, phosphorus, manganese, and iron), fiber, vitamins (C and E), carotenoids, fatty acids, polyphenols and flavonoids [3-6].

The date palm (Phoenix dactylifera) is commonly known in Arabian countries as Nakhel Al-tamr and in English as the date palm. It is a member of the family Arecaceae. Due to the extreme arid and semiarid conditions in Arabian Gulf countries, very few plants can grow. The date palm is well adapted to desert environments that are characterized by extreme temperatures and water deficiency [7]. The date palm tree is a medium to tall-sized plant, 3-15 $\mathrm{m}$ tall. It is cultivated for its edible sweet fruits [8,9]. The date palm is thoroughly associated in the culture of the people of Arabian countries. Its socioeconomic importance is not only due to its nutritive value but also for its economic importance [10]. Date fruits are considered as one of the integral parts of the Arabian diet, as an enormous source of nutrition and low-cost food [11].

In Saudi Arabia, the date palm is one of the pivotal fruit crops with an estimated 24 million palms, to produce approximately a 1.1 million ton of dates annually which represents roughly $15 \%$ of the world's production. Worldwide, more than 3000 date cultivars are known [12]. Saudi Arabia has a rich diversity of date cultivars of which Khalas, Sheshi, and Reziz are well known, especially in the Eastern Province of the Kingdom [13-17]. Although date pits represent around $11-18 \%$ of date fruit, they are considered of low market value due to their hard texture and contamination by fungi or insects during the processing of date fruits $[18,19]$. Despite several reports demonstrating the presence of high amounts of phenolic and flavonoid constituents in both the fruits and the pits of date palm, the fruits (edible and safe) are easier and cheaper to deal with comparable to pits $[4,18]$.

Cancer is a disease described by continuous uncontrolled propagation of abnormal cancer cells and regarded as one of the most prominent reasons that lead to death in the whole world [20]. Its treatment requires good approachability of the drug to the cancer cell. As a result, targeted drug delivery is regarded as a suggested methodology for cancer treatment strategy [21]. Meanwhile, the research of nanotechnology is acquiring a lot of interest recently [22], where the physical and chemical properties of active pharmaceutical ingredients or food additives could be tremendously changed through its formulation via nanotechnology.

The application of nanotechnology in targeted drug delivery systems for the treatment of cancer has increasingly been amended. Targeted drug delivery comprises three main components: the active agent, targeting moiety, and the drug carrier [23]. Nanocarrier encompasses several systems for targeting the drug such as nanoparticles, micelles, liposomes, and nanoemulsion (NE). Once the drug is encapsulated into the nanocarrier, its effectiveness is impressively improved [23].

$\mathrm{NE}$ is one of the contemporary nanoformulations that has attracted attention as it offers copious benefits over conventional emulsions owing to its nanoscale particle size that help in enhancing the bioavailability of incorporated ingredients in a way that makes them appropriate for applications. It is a colloidal system, formed when two immiscible liquids are mixed together using an appropriate surfactant to get a stable single phase [24]. This system is characterized by its ability to incorporate both hydrophilic and lipophilic drugs, being more stable, having great potential to deliver the drug to different organs in the body, in addition to the easiness of its manufacturing [25] However, for more precision and to enhance the product characteristics and the developing process, several approaches were applied for optimizing the fabricated formulation which is identified as the quality by design (QbD) concept [26].

$\mathrm{QbD}$ is an organized approach including various designs for optimizing and inspecting the relationship between the independent and the response variables obtained, which 
improves the efficiency of the study [27]. Response surface methodology (RSM), such as central composite design (CCD), is effective software that is based on mathematical and statistical techniques for studying the model and optimizes the manufacturing process [28]. Such modeling tools are dependent on the influence of several variables on the response and interpret this impact via generating mathematical equations and graphical form [29].

Consequently, the current study helps in finding an active natural candidate from the fruits of the carefully selected Khalas variety date palm and formulate the extract in the form of NEs. A twenty-three full factorial design was applied to develop DPE-NE formulations and study the effect of certain factors on their physicochemical properties. Overall, the bestselected formulation containing date palm extract was evaluated physically and chemically. Finally, the cytotoxicity of DPE and its optimized NE formulation was investigated against MCF-7 and HepG2 cell lines.

\section{Results and Discussion}

DPE was successfully obtained and used to develop various homogenous PEGylated NE formulations. All developed preparations being stable without any indication of phase separation at $25^{\circ} \mathrm{C}$.

\subsection{Estimation of Total Phenolic Content and Flavonoid Content}

The estimation of total phenolic and flavonoid contents showed that both constituents are abundant in the fruits of Khalas variety date palm. The estimated quantity of total phenolic contents in DPE and DPE-NE were $22.89 \pm 0.013$ and $22.61 \pm 0.005 \mathrm{mg} \mathrm{GAE} / \mathrm{g}$ of dry DPE, respectively. The total flavonoid contents in DPE and DPE-NE were calculated to be $9.90 \pm 0.03$ and $9.49 \pm 0.15 \mathrm{mg} \mathrm{QE} / \mathrm{g}$ of dry DPE, respectively. The total phenolic contents of the Khalas variety date palm was similar to those found in the same cultivar (around $22 \mathrm{mg} \mathrm{GAE/g} \mathrm{of} \mathrm{dry} \mathrm{plant} \mathrm{material)} \mathrm{in} \mathrm{the} \mathrm{study} \mathrm{of} \mathrm{Alhaider} \mathrm{et} \mathrm{al.} \mathrm{(2018)} \mathrm{[13],}$ while the total flavonoid contents were higher than those found in the same study (around $3 \mathrm{mg}$ QE/g of dry plant material). Reports showed the total phenolic content of some Saudi date cultivars ranged from 122 to $247 \mathrm{mg}$ GAE/100g dried extract [3], Moroccan date cultivar ranged from 171 to $353 \mathrm{mg}$ GAE/100 g dried extract, Tunisian dates cultivar ranged from 199-576 mg GAE/100 g dried extract, and Omani dates cultivar with $231 \mathrm{mg}$ GAE/100 gm of fresh fruit. Some previous investigations showed that the total flavonoid contents were estimated for Algerian cultivars (15-299 mg QE/100 g dried weight), Iranian cultivars (1-81 mg CE/100 g dried weight), and Tunisian cultivars (6-54 mg QE/100 g fresh weight) $[6,30]$. These variations and differences could be because of various parameters such as age, location, applied agricultural practices, climatic conditions, storage, or even genetic factors [3-6].

\subsection{Determination of Drug-Excipient Compatibility Study (FTIR Characterization)}

The probability of interaction between DPE and the other substances utilized in the formulation manufacturing was inspected through Fourier transform infrared spectroscopy FTIR spectroscopy as noted in Figure 1. The spectrum of DPE showed a broad peak at $3400 \mathrm{~cm}^{-1}$ that could be related to the stretching vibration of hydroxyl groups of phenolic and polyphenolic constituents present in the DPE. Other peaks were displayed at $2900-3000 \mathrm{~cm}^{-1}$ that could be attributed to stretching vibration of $\mathrm{C}-\mathrm{H}$ of aromatic skeletons like flavonoids or aromatic acids. A characteristic $\mathrm{C}=\mathrm{C}$ stretching was found at $1650 \mathrm{~cm}^{-1}$ related to aromatics and other carbonyl $\mathrm{C}=\mathrm{O}$ stretching of flavonoids or polyphenols. Other characteristic peaks related to stretching of C-C and bending vibration of C-H in aromatic rings at $1450 \sim 1500 \mathrm{~cm}^{-1}$, in addition to C-O group of polyols, such as hydroxy-flavonoids was around $1250 \mathrm{~cm}^{-1}$ [31]. Concerning the developed NE containing DPE, some peaks were around $1000-1150 \mathrm{~cm}^{-1}$ that would be related to secondary alcohols and / or to C-O- stretching ester group and vibration of $\mathrm{C}-\mathrm{C}$ of $-(\mathrm{CH} 2) \mathrm{n}$ - side chains found in oil and emulsifying agents for the preparation of NE [32,33]. The additional peak at $1750 \mathrm{~cm}^{-1}$ representing the $\mathrm{C}=\mathrm{O}$ of the ester group found in tween 80 and arachis 
oil. On the other side, the fingerprint region of DPE often existed while mixing it with other additives in PEGylated NE signifying that DPE included in the formulation had no significant chemical interaction.

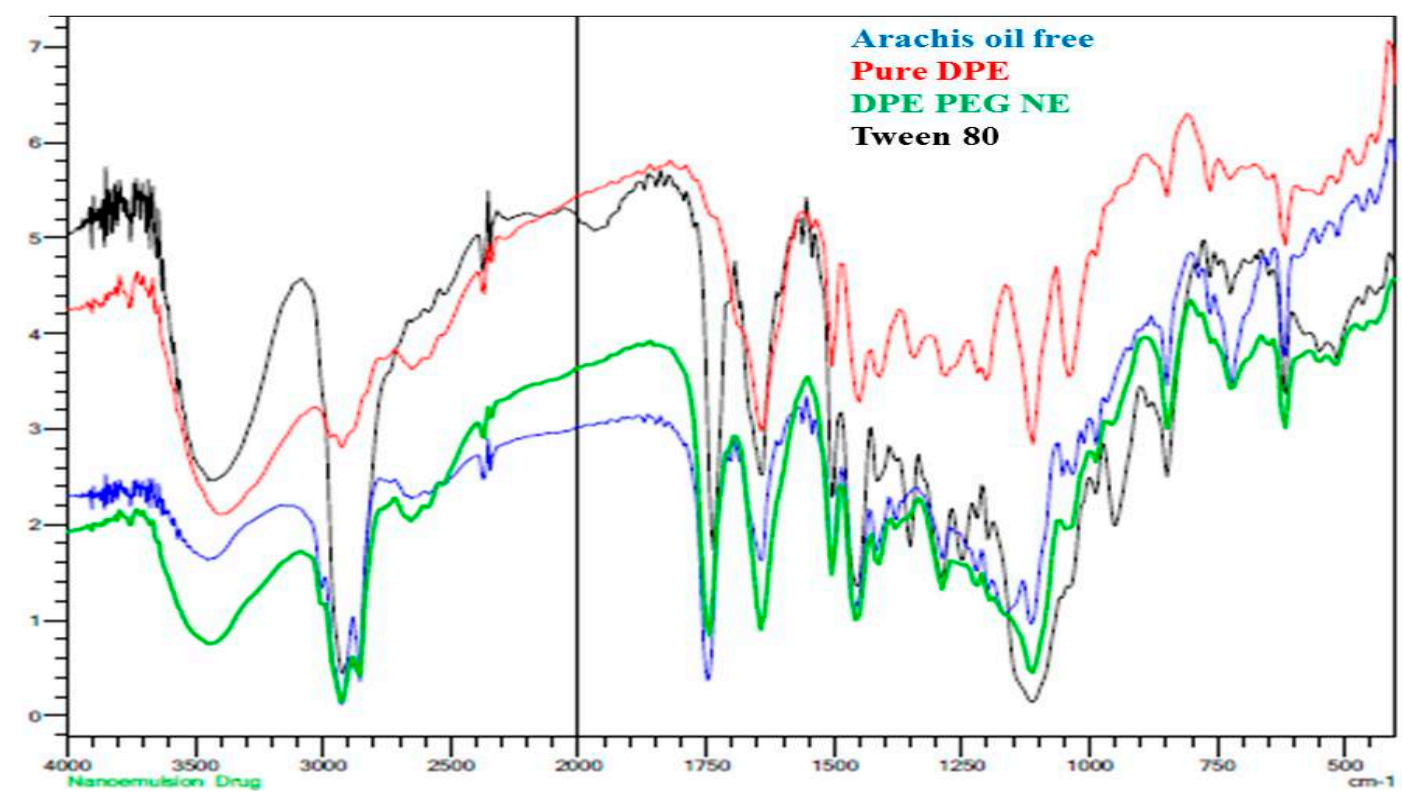

Figure 1. FTIR spectra of pure arachis oil, pure date palm extract (DPE), the developed PEG-nanoemulsion (NE), and tween 80 .

\subsection{Full Factorial Experimental Design}

\subsubsection{Fitting the Model}

The design matrix was produced by CCD software that ran 12 experiments including eight factorial points and four central points. In addition, the effect of independent variables on the response values were summarized in Table 1.

Table 1. Experimental design for DPE-NE formulations and their corresponding observed values of response.

\begin{tabular}{cccccc}
\hline \multirow{2}{*}{ Formula } & \multicolumn{2}{c}{ Independent Variables } & \multicolumn{3}{c}{ Response Values } \\
\cline { 2 - 6 } & $\mathbf{A} \mathbf{( g )}$ & $\mathbf{B}(\mathbf{g})$ & $\mathbf{Y}_{\mathbf{1}} \mathbf{( n m )}$ & $\mathbf{Y}_{\mathbf{2}} \mathbf{( \% )}$ & $\mathbf{Y}_{\mathbf{3}} \mathbf{( \% )}$ \\
\hline F1 & 0.2 & 2 & 225 & 45.4 & 3.5 \\
F2 & 0.6 & 2 & 200 & 46.5 & 6 \\
F3 & 0.68 & 1.5 & 150 & 62.8 & 6.2 \\
F4 & 0.2 & 1 & 142 & 67.6 & 3.3 \\
F5 & 0.11 & 1.5 & 175 & 61.9 & 2.4 \\
F6 & 0.4 & 0.79 & 125 & 74.7 & 4.6 \\
F7 & 0.4 & 1.5 & 170 & 58.2 & 4.8 \\
F8 & 0.4 & 1.5 & 166 & 60.8 & 5 \\
F9 & 0.6 & 1 & 130 & 70.8 & 5.8 \\
F10 & 0.4 & 1.5 & 168 & 58.6 & 5.1 \\
F11 & 0.4 & 2.2 & 235 & 40.4 & 4.7 \\
F12 & 0.4 & 1.5 & 166 & 60 & 4.9 \\
\hline
\end{tabular}

A: Surfactant concentration; B: oil concentration; $\mathrm{Y}_{1}$ particle size; $\mathrm{Y}_{2}$ : In vitro release study; $\mathrm{Y}_{3}$ : Hemolysis. 


\subsubsection{Statistical Analysis of the Data}

It is well known that when the $p$-value is lower than 0.05 , the model is considered to be statistically significant. In the current study-as apparent in Table 2-, the $p$-values detected for the three responses, Y1, Y2, and Y3 were less than 0.0001 which confirmed the significant influence of the independent variables toward the examined responses without showing any chances of error [34]. Additionally, the greater F-values of the responses support the previous illustration where lower values revealed more error in the model. Further, values of the lack of fit help to inspect how the data is fitted to the model, thus, a non-significant lack of fit is requisite to fit the model [35]. As made clear in Table 2, the observed dependent responses showed the following values of lack of fit 5.34, 3.51, and 1.74 and $p$-values of $0.1011,0.1651$ and 0.3299 for $Y 1, Y 2$, and $Y 3$ respectively which established a non-significant lack of fit.

Table 2. Statistical analysis results of responses.

\begin{tabular}{|c|c|c|c|c|c|c|}
\hline \multirow{2}{*}{ Source } & \multicolumn{2}{|c|}{$\mathbf{Y}_{1}$} & \multicolumn{2}{|c|}{$\mathrm{Y}_{2}$} & \multicolumn{2}{|c|}{$\mathbf{Y}_{3}$} \\
\hline & F-Value & $p$-Value & F-Value & $p$-Value & $F$-Value & $p$-Value \\
\hline Model & 247.23 & $<0.0001$ & 88.36 & $<0.0001$ & 122.65 & $<0.0001$ \\
\hline A & 64.32 & $0.0002 *$ & 14.43 & $0.0090 *$ & 588.76 & $<0.0001$ * \\
\hline B & 1154.38 & $<0.0001 *$ & 393.75 & $<0.0001$ * & 1.60 & 0.2523 \\
\hline $\mathrm{AB}$ & 1.38 & 0.2853 & 0.3336 & 0.5846 & 0.0000 & 1.0000 \\
\hline $\mathrm{A}^{2}$ & 1.14 & 0.3272 & 3.93 & $0.0946 *$ & 22.16 & $0.0033 *$ \\
\hline $\mathrm{B}^{2}$ & 12.75 & $0.0118 *$ & 32.55 & $0.0013 *$ & 3.16 & 0.1257 \\
\hline Lack of Fit & 5.34 & 0.1011 & 3.51 & 0.1651 & 1.74 & 0.3299 \\
\hline \multicolumn{7}{|c|}{$\mathrm{R}^{2}$ analysis } \\
\hline $\mathrm{R}^{2}$ & \multicolumn{2}{|c|}{0.9952} & \multicolumn{2}{|c|}{0.9866} & \multicolumn{2}{|c|}{0.9903} \\
\hline Adjusted $\mathrm{R}^{2}$ & \multicolumn{2}{|c|}{0.9911} & \multicolumn{2}{|c|}{0.9754} & \multicolumn{2}{|c|}{0.9822} \\
\hline Predicted $\mathrm{R}^{2}$ & \multicolumn{2}{|c|}{0.9697} & \multicolumn{2}{|c|}{0.9206} & \multicolumn{2}{|c|}{0.9499} \\
\hline Adequate Precision & \multicolumn{2}{|c|}{48.0496} & \multicolumn{2}{|c|}{28.0624} & \multicolumn{2}{|c|}{34.3150} \\
\hline
\end{tabular}

$\mathrm{Y}_{1}$ : particle size; $\mathrm{Y}_{2}$ : In vitro release study; $\mathrm{Y}_{3}$ : hemolysis; ${ }^{*}$, significant.

\subsection{Viscosity Measurement}

In regard to rheological behavior, data is displayed in Table 3. The formulated DPE-NEs exhibited a conventional viscosity hence it ranged between $2.38 \pm 0.27$ and $3.42 \pm 0.23 \mathrm{cP}$ depending on the concentration of ingredients included mainly oil and surfactant content. In fact, the results were in a proper range that could permit intravenous administration as formerly declared by Araújo et al., who estimated that it is reasonable for intravenous administration if the viscosity is lower than $3.9 \mathrm{cP}$ [36]. These outcomes were in accordance with Elsewedy et al., who assessed the viscosity of Brucine NE to be up to $3.21 \mathrm{cP}$ and established that it could safely be administered via intravenous route [37]. Further, Harun et al., estimated the viscosity of cefuroxime NE to be $1.24 \mathrm{cP}$ and stated that it is acceptable for parenteral delivery as it is below $3.9 \mathrm{cP}$ [38].

Table 3. Characterization of different DPE-NE formulations.

\begin{tabular}{cccc}
\hline Formulation & Viscosity (cp) & Formulation & Viscosity (cp) \\
\hline F1 & $3.42 \pm 0.23$ & F7 & $2.65 \pm 0.14$ \\
F2 & $2.83 \pm 0.25$ & F8 & $2.67 \pm 0.32$ \\
F3 & $2.70 \pm 0.28$ & F9 & $2.98 \pm 0.25$ \\
F4 & $3.14 \pm 0.15$ & F10 & $2.85 \pm 0.28$ \\
F5 & $2.97 \pm 0.25$ & F11 & $2.38 \pm 0.27$ \\
F6 & $2.49 \pm 0.15$ & F12 & $2.92 \pm 0.23$ \\
\hline
\end{tabular}

Values are stated as mean \pm standard deviation (SD), $n=3$. 


\subsection{Size and Size Distribution (PDI) Determination}

Particle size and PDI of the developed DPE-NE preparations were estimated and the results were displayed in Table 1 . The particle size of all NE formulations was within the nanoscale and varying from $115 \pm 1.5$ to $235 \pm 2.5$, with PDI 0.24 and 0.452 , respectively. These findings indicate that the distribution of the particle size is inside a narrow range which is good evidence for formulation stability. Truthfully, particle size and PDI are essential variables for the formulations administered intravenously since large particle sizes are clinically undesirable because of emboli formation that may happen (Araújo et al.). As well, it was previously revealed that formulations with PDI values smaller than 0.7 are considered perfect and confirm the homogeneity of the particle size in the preparation Danaei et al. [39]. It was observable that, increasing oil concentration from 1 to $2 \mathrm{~g}$ results in a subsequent increase in the particle size which could be ascribed to the increase in the dispersed phase [40]. Conversely, increasing surfactant concentration could reduce the particle size. The action of these factors on the observed response could be illustrated by the following regression equation:

$$
\mathrm{Y}_{1}=167.5-9.66 \mathrm{~A}+40.96 \mathrm{~B}-2 \mathrm{AB}-1.43 \mathrm{~A}^{2}+4.81 \mathrm{~B}^{2}
$$

Referring to the regression equation, the positive sign points to a synergistic effect however, the negative one denotes antagonistic action [27]. In the present equation, it was stated that variable (A) signified a negative influence on the particle size, though; variable (B) deliberated a positive upshot. Moreover, Figure 2A,B displayed a 2D Contour and 3D-response surface plot which exposed a non-significant effect of surfactant concentration (A) upon the particle size (Y1) of DPE-NE formulations however a substantial effect of oil concentration (B) was depicted.

$\mathbf{A}$

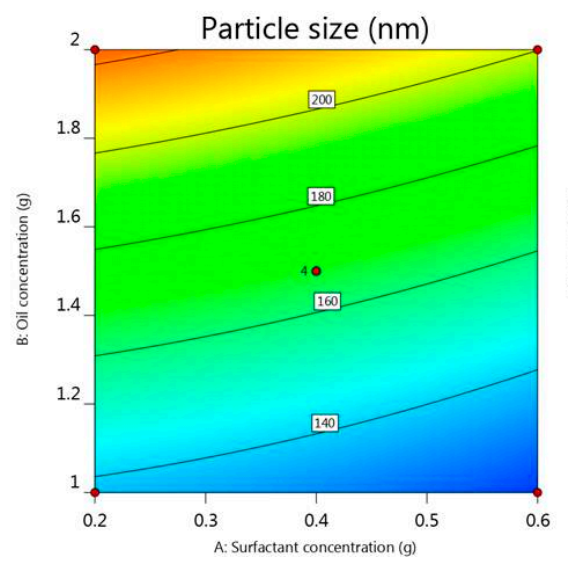

B

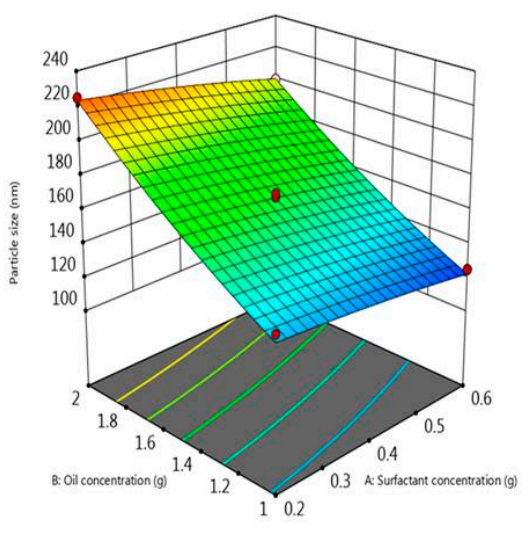

Figure 2. (A) 2D-Contour plot and (B) 3D-response surface plot representing the influence of surfactant concentration $(\mathrm{g})$ and oil concentration $(\mathrm{g})$ on particle size $(\mathrm{nm})$.

\subsection{Studies of DPE In Vitro Release from NE Formulations}

The in vitro release pattern of DPE-NE was carried out successfully and the release profile is plotted in Figure 3. It is evident from the figure that, following $24 \mathrm{~h}$, the percentage of DPE released from formulated NE was (38.4 \pm 6.5 and $74.7 \pm 6.8 \%)$ from F11 and F6 respectively. Actually, decreasing oil concentration would result in a relative decrease in the particle size that offers a large surface area which in turn provides a higher percentage of drug released [41]. On the other hand, increasing surfactant concentration could increase the drug solubility in the aqueous media that resulted in improving the drug release [42]. 


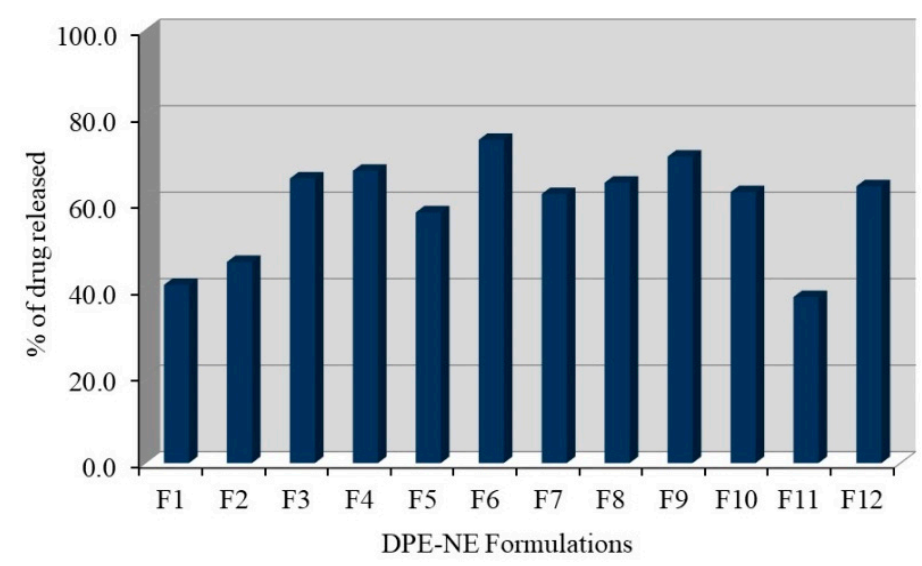

Figure 3. Representing DPE in vitro Release study from different NE formulations in phosphate buffer $\mathrm{pH} 7.4$ at $37^{\circ} \mathrm{C}$. Results are stated as the mean $\pm \mathrm{SD}$ of three experiments.

Furthermore, the 2D-Contour and 3D-response surface plot portrayed in Figure 4, illustrates the effect of the independent variables on the investigated response $\left(Y_{2}\right)$. It was detected that surfactant concentration (A) exerted a significant synergistic effect on the amount of DPE released $\left(\mathrm{Y}_{2}\right)$. Nevertheless, oil concentration (B) possessed an antagonistic effect $(p<0.05)$ on the in vitro release study. The fitted mathematical regression equation that describes the interaction of these independent variables and their considerable effects on the responses is given below:

$$
\mathrm{Y}_{2}=63.4+2.44 \mathrm{~A}-12.75 \mathrm{~B}+0.52 \mathrm{AB}-1.42 \mathrm{~A}^{2}-4.1 \mathrm{~B}^{2}
$$

A
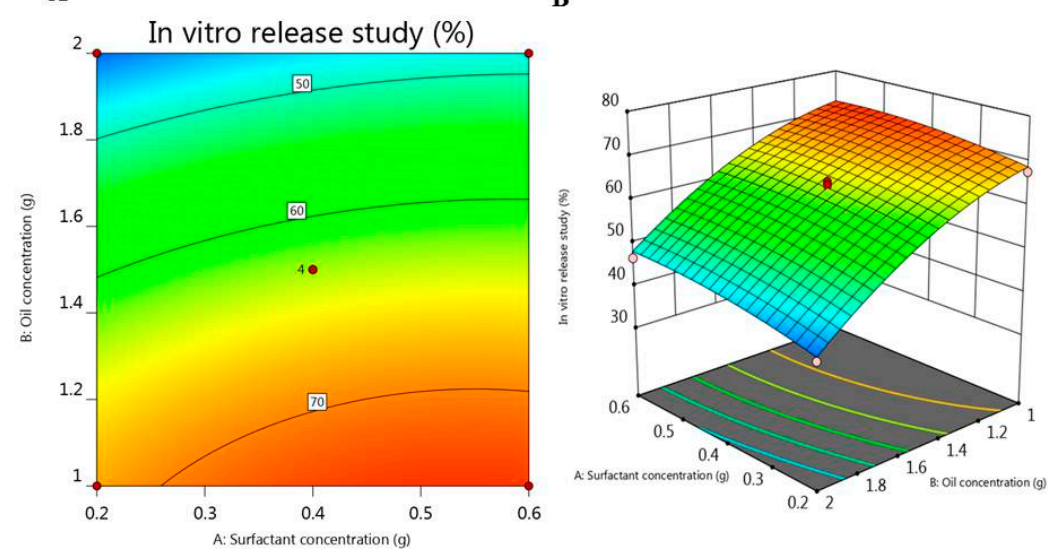

Figure 4. (A) 2D-Contour plot and (B) 3D-response surface plot representing the effect of surfactant concentration $(\mathrm{g})$ and oil concentration $(\mathrm{g})$ on in vitro release study $(\%)$.

\subsection{Hemolytic Activity}

The hemolytic activity of the fabricated NE preparations was estimated in order to validate whether the formulations may come up with harmful effects on the biological membranes [43], and the data were demonstrated in Table 1. The percentage of hemolysis following incubation for $30 \mathrm{~min}$ was in the range of 2.4 and $6.2 \%$ in all formulations proposing that these preparations are harmless and suitable for intravenous administration. Likewise, as revealed in Figure 5, the surfactant concentration (A) employed a significant positive effect on the $\%$ of hemolytic activity $\left(\mathrm{Y}_{3}\right)$, hence increasing surfactant concentration would result in a relative increase in the hemolytic activity of the preparations. Yet, oil concentration (B) did not greatly affect this response. The regression equation for 
hemolysis response $\left(\mathrm{Y}_{3}\right)$ attained from response surface methodology is stated in the following equation:

$$
\mathrm{Y}_{3}=4.95+1.29 \mathrm{~A}+0.067 \mathrm{~B}+5.15 \mathrm{AB}-0.28 \mathrm{~A}^{2} \pm 0.10 \mathrm{~B}^{2}
$$

A

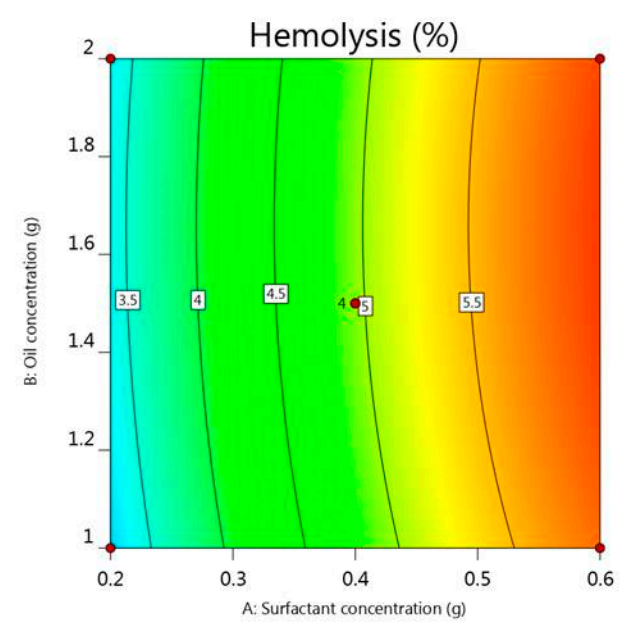

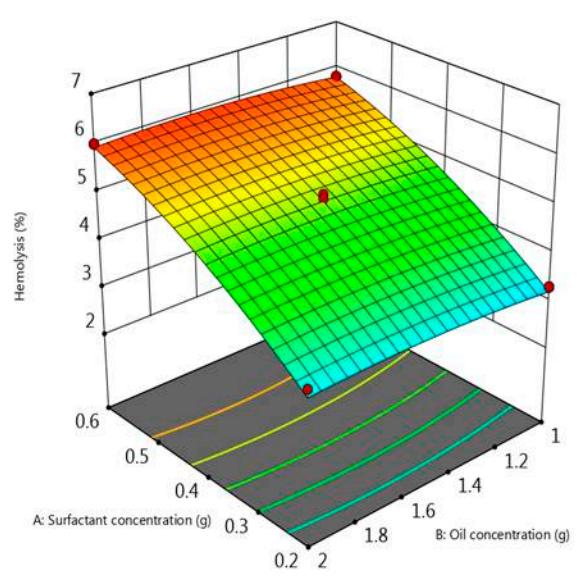

Figure 5. (A) 2D-Contour plot and (B) 3D-response surface plot representing the influence of surfactant concentration (g) and oil concentration (g) on hemolysis (\%).

\subsection{Optimization of Independent Variables}

The objectives of the optimization process were to select the optimal characteristics and appropriate levels of constraints (Table 4) to get a formulation with proper features based on the higher desirability value [44]. The optimized DPE-NE formulation was selected depending on targeting the particle size to a range of 140 to $160 \mathrm{~nm}$ and in vitro release study to a range of 55 to $65 \%$ and minimizing the percentage of hemolysis.

Table 4. Objectives of the optimization process.

\begin{tabular}{ccccc}
\hline \multirow{2}{*}{ Independent Variable } & \multirow{2}{*}{ Symbol } & \multicolumn{3}{c}{ Level of Variation } \\
\cline { 3 - 5 } & & $\mathbf{- 1}$ & $\mathbf{0}$ & $\mathbf{+ 1}$ \\
\hline Surfactant concentration $(\mathrm{g})$ & $\mathrm{A}$ & 0.2 & 0.4 & 0.6 \\
\hline Oil concentration $(\mathrm{g})$ & $\mathrm{B}$ & 1.5 & 2 & 2.5 \\
\hline Dependent variables & Symbol & \multicolumn{3}{c}{ Constraints } \\
\hline Particle size $(\mathrm{nm})$ & $\mathrm{Y}_{1}$ & & In range $(140-160 \mathrm{~nm})$ \\
In vitro drug release $(\%)$ & $\mathrm{Y}_{2}$ & \multicolumn{3}{c}{ In range $(55-65 \%)$} \\
Hemolysis $(\%)$ & $\mathrm{Y}_{3}$ & & Minimize \\
\hline
\end{tabular}

The predicted values for the optimized DPE-NE formulation assumed by the software were displayed in Table 5, in addition to Figure 6 that suggests the higher desirability value (0.826). CCD predicted that the independent variables used in formulating the optimized preparation were $0.2 \mathrm{mg}$ surfactant and $1.258 \mathrm{mg}$ oil. The optimized NE formulation was then developed using the predicted values and was compared to the observed experimental values of the optimized formulation recorded in Table 5. Ultimately, the values of the experimental responses were in accordance with that of the predicted response. 
Table 5. Predicted and observed experimental value of response at optimized conditions.

\begin{tabular}{ccc}
\hline Response & Predicted Values & Experimental Values \\
\hline$Y_{1}(\mathrm{~nm})$ & 156.067 & $159.33 \pm 3.4$ \\
$\mathrm{Y}_{2}(\%)$ & 65 & $64.3 \pm 1.82$ \\
$\mathrm{Y}_{3}(\%)$ & 3.314 & $3.2 \pm 0.15$ \\
\hline
\end{tabular}

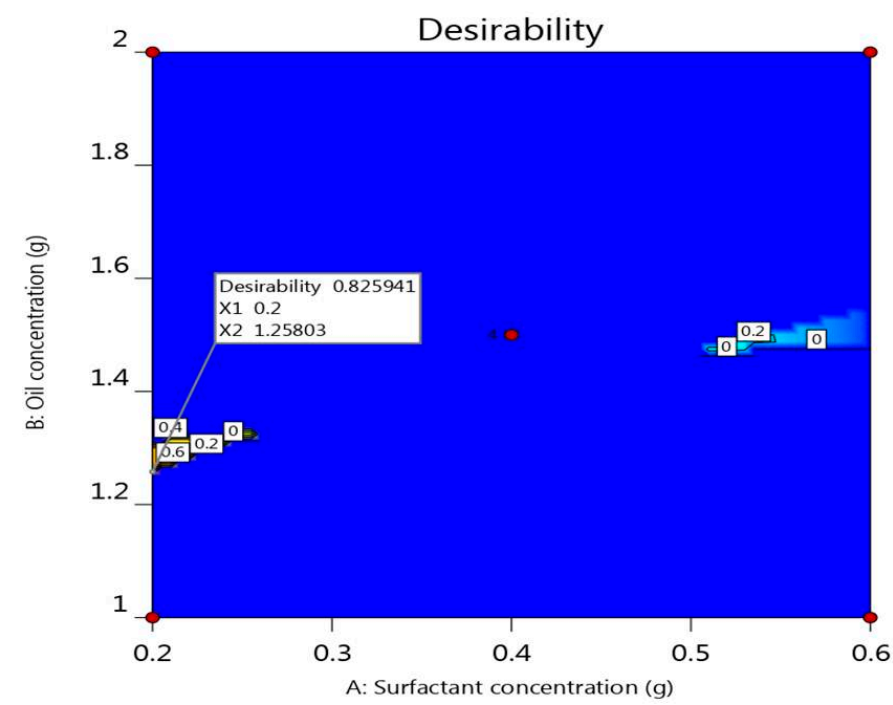

Figure 6. Optimization figure screening the influence of surfactant concentration and oil concentration on overall desirability.

Based on the previous investigations, a new formula was developed (PEG-NE) along with its naked counterpart (NNE), and both were subjected to certain further studies.

\subsection{Particle Size and Zeta Potential Assessment}

The measurement of particle size and estimating zeta potential of optimized formulation and its naked counterpart was determined and the results are shown in Figure 7A,B. It was detected that (NNE) showed a particle size $260 \pm 5.5 \mathrm{~nm}$ and (PDI) 0.22 which is regarded as a higher value if compared to that of PEG-NE that recorded particle size $159.33 \pm 3.4$ with (PDI) 0.25 as presented in Figure 7C,D. This finding could suggest the upshot of PEGylation on particle size and the homogeneity of the NE formulation whereas uniformity of particle size has a great impact on the therapeutic efficiency of the formulation [45]. Regarding zeta potential, PEGylated NEs demonstrated a decline in the negative charge of the formulation surface $(3.23 \pm 0.26)$ compared to their naked counterpart $(-24.6 \pm 0.51)$ which is ascribed to the coating of the surface by PEG [46].
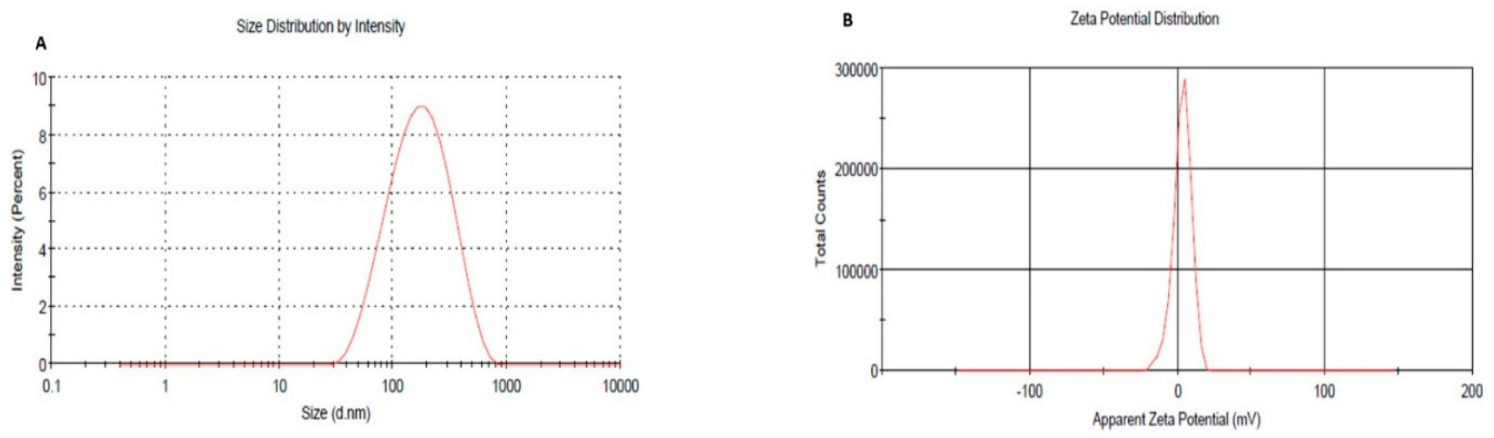

Figure 7. Cont. 
C

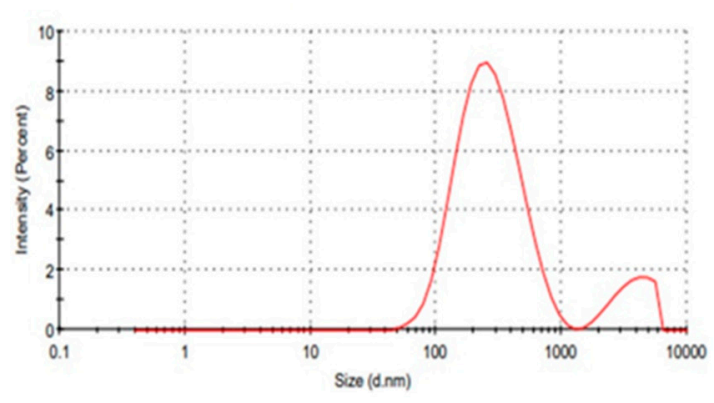

D Zeta Potential Distrbution

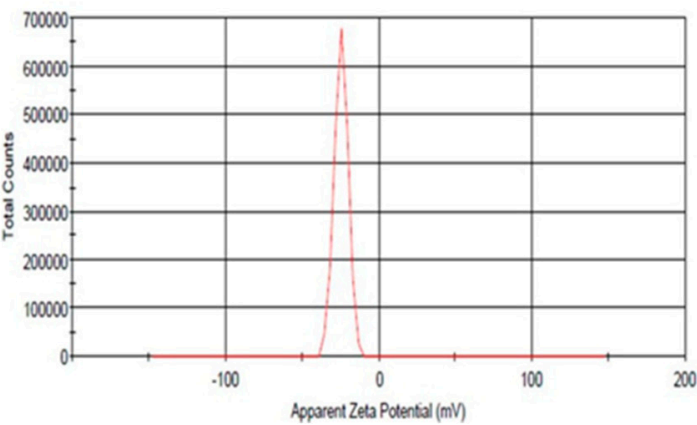

Figure 7. (A) Particle size of optimized PEG-NE; (B) Zeta potential of optimized PEG-NE (C) Particle size of naked-NE; (D) Zeta potential of naked-NE.

\subsection{Determination of Serum Protein Associated on the Surface of NE Quantitatively}

The quantity of serum protein attached to the PEG-NE and its counterpart surface was measured and data is obvious in Figure 8. PEG-NE exhibited a significant minor quantity of serum protein attached on its surface $(15.33 \pm 2.08 \mu \mathrm{g} / \mu \mathrm{mol}$ total lipid) which is significantly different from the quantity adsorbed on its naked counterpart (NNE) surface $(27.6 \pm 2.3 \mu \mathrm{g} / \mu \mathrm{mol})(p<0.05)$. It could be established that the inferior quantity of serum protein detected on the surface of PEG-NE was ascribed to the PEG coat that resulted in a fixed aqueous layer thickness (FALT) phenomenon. FALT would have the capability to protect the formulation from being recognized by serum proteins and avoid its interaction with the PEG-NE outer surface [47]. In point of fact, the quantity of protein associated on the surface of NNE was expected to be higher than the recorded value. This is actually ascribed to the presence of tween 80 in the preparation which has a hydrophilic ethylene head group, that is likewise found in PEG-DSPE. This actively resists protein surface coatings, thus it could exhibit similar activity to PEG-DSPE [48].

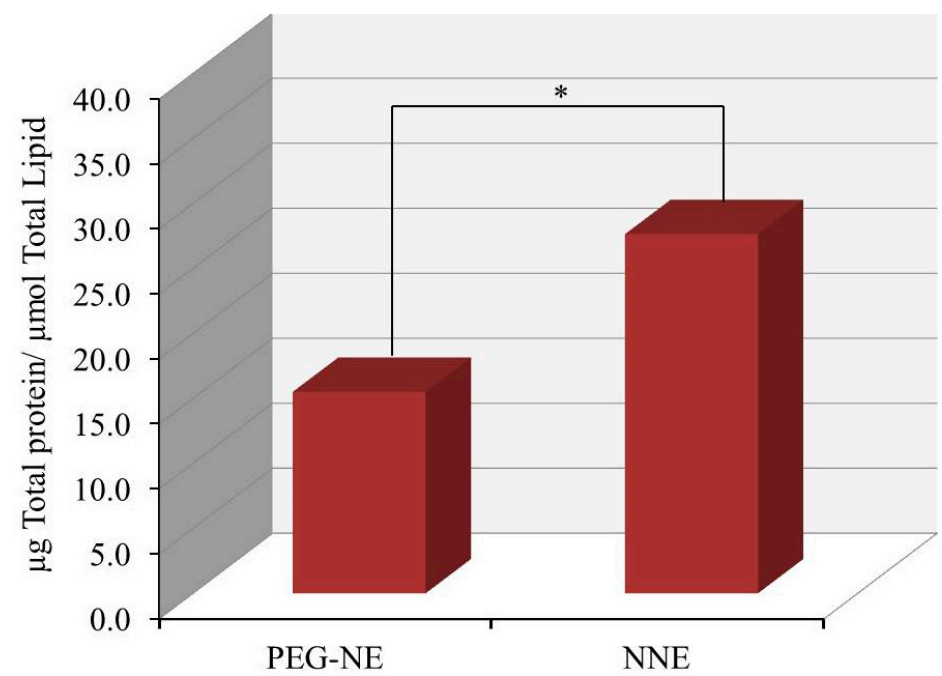

Figure 8. Total quantity of serum proteins adsorbed on NNE and PEG-NE surface. Results are stated as the mean with the bar showing S.D. $(n=3) .{ }^{*} p<0.05$ if compared to naked counterpart.

\subsection{Studies of DPE In Vitro Release from Optimized NE (before and after Serum Incubation)}

The in vitro drug release pattern of DPE from PEG-NE formulation and its naked counterpart was accomplished and the profile was graphically plotted in Figure 9. Following $24 \mathrm{~h}$, the study denotes that PEG-NE formulation showed $(64.3 \pm 2.7 \%)$ of DPE released compared to that released from NNE (97.17 $\pm 5.79 \%)$. It is manifested that the amount of the drug released from PEG-NE was significantly lower than that released from 
NNE. This actually could be owed to the good stability of PEGylated NE, in addition to the rigidization of the PEG-NE surface that resulted in a diminution of drug release [49].

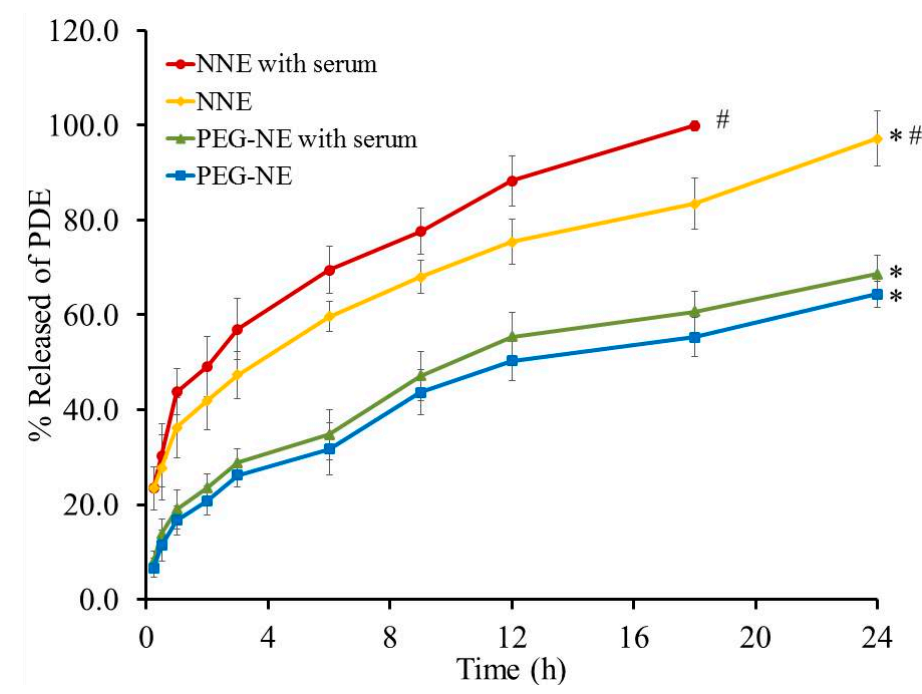

Figure 9. Study of DPE in vitro release from NE formulations before and after serum incubation. Results are stated as the mean with the bar showing S.D. $(n=3) .{ }^{*} p<0.05$ if compared to NNE with serum. \# $p<0.05$ if compared to PEG-NE with serum.

On the other side, following incubating NE formulations with an equivalent amount of $10 \%$ serum, the release of the drug was estimated over $24 \mathrm{~h}$ and the effect is explained in the same figure (Figure 9). It was evident that serum accelerates the release of the drug from $\mathrm{NNE}$ as it reached $99.9 \pm 1.1 \%$ over $18 \mathrm{~h}$. Contrariwise, serum failed to affect in vitro release from PEG-NE since it achieved $68.6 \pm 3.9 \%$ after $24 \mathrm{~h}$ compared to that without serum incubation $(64.33 \pm 2.7 \%)$. In view of that, there is an insignificant difference between in vitro release from PEG-NE before and after serum incubation which confirms the crucial role of PEG. The boosted release of drug from NNE could be elucidated to the statement of MAC assembly (membrane attack complex), which act to form lytic holes and permeable areas at the surface of the target surface [50]. Correspondingly, it was declared by Shehata et al. [51] that naked niosome subjected to attack by serum protein gave rise to formulation distraction leading to a higher amount of Doxorubicin released. Currently, about $66 \%$ of the running clinical trials are focused on cancer treatment utilizing nanotechnology. In order to be successfully introduced to the market, both FDA and EMA necessitate that nanoformulations must have maximum safety, efficacy, and quality criteria applied to final products [52]. The quality of nanoformulations includes physical evaluation (particle size, size distribution, and surface charge), in addition to the drug loading, in vitro drug release profile, and size stability during storage and after contacting the biological solutions [53].

\subsection{In Vitro Cytotoxicity}

The MTT colorimetric assay was carried out to evaluate cell viability of DPE PEG-NE against MCF-7 and HepG2 cells and the results were depicted in Figure 10. It is perceptible that a significant decline in the cell proliferation for PEG-NE was distinguished along with relevant IC50 values of $18.6 \pm 2.4$ and $13.5 \pm 1.8 \mu \mathrm{g} / \mathrm{mL}$ for MCF-7 and HepG2 cells respectively if compared to free DPE that exhibited IC50 value of $101.3 \pm 6.2 \mu \mathrm{g} / \mathrm{mL}$ on MCF-7 cells and $48.3 \pm 4.4 \mu \mathrm{g} / \mathrm{mL}$ for HepG2 cells $(p<0.05)$. It was remarkable that incorporation of DPE within NE formulation stimulated cytotoxic activity that is higher than the free DPE [54]. As well, a significant diminution was detected in cell viability amongst PEG-NE and its corresponding placebo NE $(p<0.05)$. Remarkably, it was identified that there was a significant difference between free drug and placebo NE while using greater concentrations $(25,50$, and $100 \mu \mathrm{g} / \mathrm{mL})$ in the case of MCF-7. However, a significant difference was detected between them upon using lower concentrations ( 5 
up to $100 \mu \mathrm{g} / \mathrm{mL}$ ) in regard to HepG2 cells, which could be owing to the composition of the NE itself. Comprehensively, dealing with PEG-NE incorporating DPE exhibited a significant cell viability reduction in a dose-dependent manner, which could be attributed to increasing the drug solubility and boosting its cellular uptake once prepared in NE form [55].
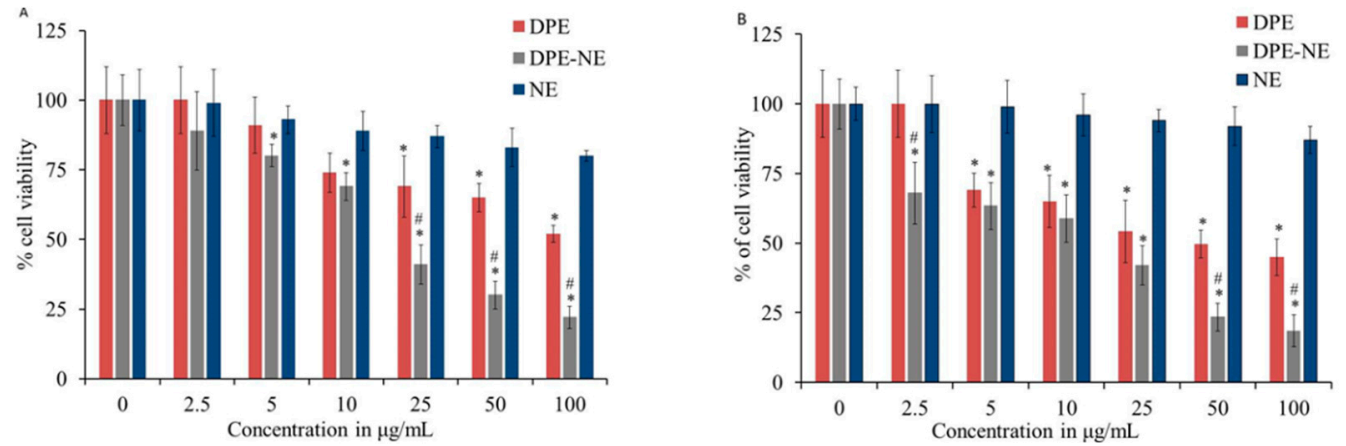

Figure 10. Cell viability evaluation of free DPE, optimized PEGylated DPE, and blank NE against (A) MCF-7 and (B) HepG2 cell lines following $48 \mathrm{~h}$ incubation. Results are stated as the mean \pm S.D * Statistically significant with blank NE $(p<0.05)$. \# Statistically significant with free drug (DPE) $(p<0.05)$.

\section{Material and Methods}

\subsection{Material}

Arachis oil and tween 80 were obtained from Sigma Aldrich (St. Louis, MO, USA). Distearoyl phosphatidylethanolamine-N-(methoxy poly (ethylene glycol)-2000) (PEG-DSPE) was purchased from Lipoid LLC, (Newark, NJ, USA). Fetal bovine serum (FBS) was obtained from Sigma Aldrich (St. Louis, MO, USA). Total protein and Total Lipid Colorimetric kits purchased from United Diagnostics Industry, (Dammam, Saudi Arabia). Tetrazolium dye (MTT reagent) was procured from Loba Chemie (Mumbai, India). All other reagents were of the finest grade available.

\subsection{Attainment of Date Palm Extract (DPE)}

\subsubsection{Dates Identification and Collection}

Fruits of Khalas cultivar date palm were purchased from the local markets in Al-Ahsa, Eastern Province of Saudi Arabia. The date palm fruits were collected in the palatable stage and identified by experts and taxonomists in the date and palm center, King Faisal University, Al-Ahsa, Saudi Arabia. A voucher specimen of fruit Khalas date palm is deposited in the Herbarium of Department of Pharmaceutical Sciences, College of Clinical Pharmacy, King Faisal University, Al-Ahsa, Saudi Arabia (20-Sept-KH).

\subsubsection{Crude Extract Preparation}

A weight of $250 \mathrm{~g}$ of dried flesh of fruits of Khalas date palm was macerated in $2.5 \mathrm{~L}$ of $70 \%$ methanol in distilled water applying cold maceration technique (1:10 ratio) for $48 \mathrm{~h}$ then filtered using the Whatman filter paper No.1. Methanol was selected as a solvent for extraction because of its power to extract all the various components from the plant material [56,57]. The process of extraction was repeated three times. The compiled extracts from the triplicate extraction process were then concentrated under reduced pressure and the remaining concentrated extract was freeze-dried to give the dried date palm methanol extract (DPE) and then was kept in dried condition for further experiments.

\subsubsection{Estimation of Total Phenolic Content}

The total phenolic content of DPE was determined according to the method previously reported by Hany et al. [58]. Folin-Ciocalteu reagent protocol was applied in the assay of total phenolic content using gallic acid as the standard. To estimate the total phenolic 
content in DPE-NE, equivalent to $1 \mathrm{mg}$ of DPE in NE preparation was diluted in $3 \mathrm{~mL}$ of distilled water and stirred on a magnetic stirrer for 1 hour followed by $30 \mathrm{~s}$ of sonication. The resultant solution was cooled to room temperature and filter through 0.22 micro-syringe filters to give a clear solution. The concentration of phenolic contents was expressed as gallic acid equivalent (GAE) for $1 \mathrm{~g}$ of dried extract.

\subsubsection{Estimation of Total Flavonoid Content}

The total flavonoid content of DPE was determined according to the protocol reported by Hany et al. [59]. Aluminum chloride ( $2 \% v / v)$ assay was implemented in the assay of total flavonoid content, quercetin was used as a standard. A stock solution prepared for the estimation of total phenolic contents in DPE-NE was used to estimate the total flavonoid content. The concentration of the total flavonoids was expressed as mg quercetin equivalent $(\mathrm{QE})$ for $1 \mathrm{~g}$ of the dried extract.

\subsection{Drug-Excipient Compatibility Study (FTIR Characterization)}

The interaction between the drug and excipients included in the formulation was investigated utilizing Fourier transform infrared spectroscopy, (FTIR spectrophotometer, SHIMADZU, IRAFFINITY-1S, Japan) using the KBr pellet method. The KBr plate disc was prepared and almost $5 \mu \mathrm{L}$ of the sample was placed on that disc and allowed to be dried in a vacuum. The samples were examined for their FTIR spectra between 4000 and $400 \mathrm{~cm}^{-1}$ [60]. In the current study, pure DPE and its formulated NE were analyzed for their spectra.

\subsection{Experimental Design Study}

In order to establish the current optimization study and after preliminary investigations, specific parameters were selected as independent variables such as different concentrations of surfactant (A) and oil (B). Therefore, Design-Expert version 12.0 software (Stat-Ease, USA) was implemented for developing a three-level and two-factor (32) factorial design. Each independent variable was explored at three levels to assess their influences on three responses; namely, particle size (Y1), \% of in vitro drug release following $24 \mathrm{~h}$ (Y2), and \% of hemolysis (Y3). Table 4 displayed three different levels $(-1,0,1)$ that were applied for the independent variables, and their level of variation, (Y1), (Y2), and (Y3) were regarded as the dependent variable. ANOVA test provided by the software was performed to check the statistical analysis of the data such as p-value, F-value, R2, predicted R2, adjusted R2, and lack of fit. Consequently, certain model graphs were generated such as 2D Contour and 3D-response surface plot in order to demonstrate the interaction between the studied variables and responses. Moreover, mathematical modeling was conceded by using the following equation:

$$
Y=b_{0}+b_{1} A+b_{2} B+b_{12} A B+b_{11} A^{2}+b 22 B^{2}
$$

where $\mathrm{Y}$ indicates the dependent variable, whereas $\mathrm{b}_{0}$ is the intercept, $\mathrm{b}_{1}, \mathrm{~b}_{2}, \mathrm{~b}_{12}, \mathrm{~b}_{11}$, and $b_{22}$ signifies the regression coefficients; $A$ and $B$ indicate the main factors; $A B$ represents the interactions between main factors; $A^{2}$ and $B^{2}=$ polynomial terms.

\subsection{Development of PEGylated DPE-NES}

Several NE formulations of DPE were developed using the specified amounts of constituents. $175 \mathrm{mg}$ of DPE powder were added to different concentrations of arachis oil followed by vortexing. Various concentrations of surfactant (tween 80) in addition to $50 \mathrm{mg}$ of PEG-DSPE were mixed with the oily phase mixture. The aqueous phase and oily phase were heated separately, after that, the aqueous phase was gradually added while homogenization at 20,000 rpm for $15 \mathrm{~min}$ to the oily phase using a high shear homogenizer (T 25 digital Ultra-Turrax, IKA, Staufen, Germany). The NEs formed instantly after homogenization followed by sonication for 1 min using a probe sonicator (XL-2000, 
Qsonica, Newtown, CT, USA) [29]. The matrix of 12 experimental formulations was assembled by (CCD) along with their observed values of response as illustrated in Table 1.

\subsection{Characterization of DPE-NE Formulations}

\subsubsection{Viscosity}

The formulations were examined for their rheological behavior at room temperature utilizing Brookfield viscometer (DV-II + Pro, Middleboro, MA, USA) [61].

\subsubsection{Size and Size Distribution (PDI) Determination}

DPE-NEs were analyzed for their particle size and PDI using the Zetasizer apparatus (Malvern Instruments Ltd., Worcestershire, UK). These were determined at $25{ }^{\circ} \mathrm{C}$ by assessing the dynamic light scattering at a $90^{\circ}$ scattering angle [62].

\subsection{Study of DPE In Vitro Release from NE Formulations}

Agilent Fiber optics dissolution system (Agilent Technologies, California, USA) was utilized for estimating the percentage of DPE released from the developed NE formulations. Briefly, a glass tube closed from one side with cellophane membrane (MWCO 2000-15,000) was used to retain $2 \mathrm{~mL}$ of $\mathrm{NE}$ formulation. The tubes were utilized instead of baskets and suspended into the apparatus. A system of $750 \mathrm{~mL}$ PBS 7.4 was adjusted to rotate at $50 \mathrm{rpm}$ and conserved at $37 \pm 0.5{ }^{\circ} \mathrm{C}$. At definite time intervals $(0.25,0.5,1,2$ until $24 \mathrm{~h})$, Samples were measured at $\lambda \max 261 \mathrm{~nm}$ [37]. Each experiment was performed in triplicate.

\subsection{Hemolytic Activity}

This investigation was implemented using blood obtained from rats by a syringe containing traces of heparin. Centrifugation for the collected rat blood was done at $1500 \times g$ for $10 \mathrm{~min}$ at $20^{\circ} \mathrm{C}$. Next, plasma was detached and substituted with an equivalent amount of PBS pH 7.4 followed by centrifugation, and this step was repeated three times. In a water bath adjusted at $37^{\circ} \mathrm{C}$, one $\mathrm{mL}$ of each $\mathrm{NE}$ formulation was incubated with an identical volume of erythrocyte suspension for $30 \mathrm{~min}$. Afterward, the samples were subjected to $10 \mathrm{~min}$ centrifugation at $3000 \times g$ in order to separate the released hemoglobin from erythrocytes. The supernatant was diluted with PBS 7.4 and analyzed for their absorbance at $\lambda \max 550 \mathrm{~nm}$. For control, erythrocytes were incubated only with PBS or mixing with $1 \mathrm{~mL}$ of Triton-X $100(1 \%)$ to attain $100 \%$ hemoglobin release [37].

\subsection{Development of Naked DPE-NE}

Based on the experimental design study, one optimized NE preparation (PEG-NE) was predicted and developed. Afterward, it was necessary to develop its naked counterpart for further studies. For naked DPE-NE fabrication, the same procedure for developing PEGylated NE was followed as previously stated nevertheless without adding PEG-DSPE.

\subsection{Zeta Potential Measurement}

Zeta potential of both naked and PEGylated DPE-NE were estimated at room temperature using Zetasizer apparatus (Malvern Instruments Ltd., Worcestershire, UK). Zeta potential was measured in order to assess the NE surface charge by determining the electrophoretic mobility.

\subsection{Determination of Serum Protein Associated on the Surface of NE Quantitatively}

One milliliter from both naked and PEGylated NE formulation was incubated at 37 ${ }^{\circ} \mathrm{C}$ separately for $30 \mathrm{~min}$ with an equal volume of fresh rat serum. Thereafter, the NE formulations were passed over the Sepharose CL-4B gel column to separate the mixture from the bulk serum proteins. NEs were collected and upon using Total protein and Total Lipid Colorimetric kits, a quantitative measurement of the amount of protein attached on the NE surfaces was performed [63]. 


\subsection{Studies of DPE In Vitro Release from Optimized NE (before and after Serum Incubation)}

Regarding in vitro investigation, the same technique mentioned previously was monitored in order to detect the percentage of DPE released from PEG-NE and NNE preparation. The same technique was tracked for both formulations following being incubated with an equivalent amount of $10 \%$ serum [37].

\subsection{In Vitro Cytotoxicity}

The cytotoxicity of DPE and its optimized NE formulation was studied on MCF-7 and HepG2 cell lines using MTT assay $[64,65]$. Concisely, a 96-well plate was used for seeding 5000 cells and treating them for $48 \mathrm{~h}$ with adjusted concentrations of DPE, optimized PEG-NE along with the placebo NE. Subsequently, to determine the cytotoxicity, MTT was added to each well in the plat and incubated for $4 \mathrm{~h}$. Then, the media was detached, followed by adding DMSO to every single well and shake for $10 \mathrm{~min}$. The optical density was estimated at $570 \mathrm{~nm}[66]$.

\subsection{Statistics}

The values were validated as mean \pm SD by applying the experiments three times at least. Student's t-test was applied to verify the statistical differences between the groups. A one-way analysis of variance (ANOVA) followed by the least significant difference (LSD) as a post-hoc test was used to compare data from treated groups and the control group with each other. Statistical analysis was carried out using SPSS statistics software, version 9 (IBM Corporation, Armonk, NY, USA). The samples were deliberated statistically significant from each other if $p<0.05$.

\section{Conclusions}

In the present investigation, date palm extract powder could be successfully obtained via several production phases then incorporated into nanoemulsion formulation. Response surface methodology was a valuable technique for exploring the influence of independent variables on the response values where the optimized formulation was predicted through the desirability function. The developed PEG-NE demonstrated suitable particle size, PDI, and zeta potential that represent a vital part in nanoemulsion stability intended for intravenous administration. The quantity of serum protein attached to the PEG-NE surface was considerably small and DPE in vitro release from PEG-NE was effectively extended over $24 \mathrm{~h}$. Cytotoxic evaluation proposes positive activity of PEGylated NE of DPE toward MCF-7 and HepG2 cancer cell lines. The PEGylated NE of DPE of Khalas cultivar will open up a new future horizon for adjuvant therapy for cancer treatment.

Author Contributions: Conceptualization, funding acquisition, methodology, writing-review and editing, writing-original draft preparation and supervision, H.E.K.; methodology, validation, formal analysis, writing-review and editing, investigation, N.K.A. and T.M.S.; methodology, formal analysis, review and editing, H.M.D.; formal analysis, methodology, writing-review and editing, H.-I.M.I.; methodology, writing-review and editing, P.M.E. and L.I.B.-E.; Conceptualization, supervision, writing-original draft preparation, K.M.; methodology, software and writing-original draft preparation, H.S.E. All authors have read and agreed to the published version of the manuscript.

Funding: This research was funded by Deanship of Scientific Research (DSR), King Faisal University, Saudi Arabia, Research group project, Grant number (1811002).

Institutional Review Board Statement: Not applicable.

Informed Consent Statement: Not applicable.

Data Availability Statement: Did not report any data.

Acknowledgments: The authors thank the Deanship of Scientific Research (DSR), King Faisal University, Saudi Arabia for funding this research group project, Grant number (1811002) and College of Clinical Pharmacy, King Faisal University. 
Conflicts of Interest: The authors declare that there is no conflict of interest.

\section{References}

1. Saafi, E.B.; El Arem, A.; Issaoui, M.; Hammami, M.; Achour, L. Phenolic content and antioxidant activity of four date palm (Phoenix dactylifera L.) fruit varieties grown in Tunisia. Int. J. Food Sci. Technol. 2009, 44, 2314-2319. [CrossRef]

2. Boeing, H.; Bechthold, A.; Bub, A.; Ellinger, S.; Haller, D.; Kroke, A.; Leschik-Bonnet, E.; Müller, M.J.; Oberritter, H.; Schulze, M. Critical review: Vegetables and fruit in the prevention of chronic diseases. Eur. J. Nutr. 2012, 51, 637-663. [CrossRef] [PubMed]

3. Mohamed, S.A.; Awad, M.A.; El-Dengawy, E.-R.F.; Abdel-Mageed, H.M.; El-Badry, M.O.; Salah, H.A.; Abdel-Aty, A.M.; Fahmy, A.S. Total phenolic and flavonoid contents and antioxidant activities of sixteen commercial date cultivars grown in Saudi Arabia. RSC Adv. 2016, 6, 44814-44819. [CrossRef]

4. Hussain, M.I.; Semreen, M.H.; Shanableh, A.; Khattak, M.N.K.; Saadoun, I.; Ahmady, I.M.; Mousa, M.; Darwish, N.; Radeef, W.; Soliman, S.S. Phenolic composition and antimicrobial activity of different Emirati date (Phoenix dactylifera L.) pits: A comparative study. Plants 2019, 8, 497. [CrossRef] [PubMed]

5. Brima, E.I. Evaluation of Selected Essential Elements in Khalas Dates from Date Palm Determined by Inductively Coupled Plasma-Mass Spectrometry. Int. J. Anal. Chem. 2019, 2019. [CrossRef] [PubMed]

6. Alahyane, A.; Harrak, H.; Ayour, J.; Elateri, I.; Ait-Oubahou, A.; Benichou, M. Bioactive compounds and antioxidant activity of seventeen Moroccan date varieties and clones (Phoenix dactylifera L.). South Afr. J. Bot. 2019, 121, 402-409. [CrossRef]

7. Manickavasagan, A.; Essa, M.M.; Sukumar, E. Dates: Production, Processing, Food, and Medicinal Values; CRC Press: Boca Raton, FL, USA, 2012.

8. Al-Mssallem, I.S.; Hu, S.; Zhang, X.; Lin, Q.; Liu, W.; Tan, J.; Yu, X.; Liu, J.; Pan, L.; Zhang, T. Genome sequence of the date palm Phoenix dactylifera L. Nat. Commun. 2013, 4, 1-9. [CrossRef]

9. Vayalil, P.K. Antioxidant and antimutagenic properties of aqueous extract of date fruit (Phoenix dactylifera L. Arecaceae). J. Agric. Food Chem. 2002, 50, 610-617. [CrossRef]

10. Dayang, J.; Reuben, C.; Raji, F. Nutritional, socioeconomic and health benefits of dates. Int. J. Food Nutr. Sci. $2014,3,63$.

11. Baliga, M.S.; Baliga, B.R.V.; Kandathil, S.M.; Bhat, H.P.; Vayalil, P.K. A review of the chemistry and pharmacology of the date fruits (Phoenix dactylifera L.). Food Res. Int. 2011, 44, 1812-1822. [CrossRef]

12. Rivas, M.; Barbieri, R.L.; Maia, L.C.d. Plant breeding and in situ utilization of palm trees. Ciência Rural 2012, 42, 261-269. [CrossRef]

13. Alhaider, I.A.; Mohamed, M.E.; Ahmed, K.; Kumar, A.H. Date palm (Phoenix dactylifera) fruits as a potential cardioprotective agent: The role of circulating progenitor cells. Front. Pharmacol. 2017, 8, 592. [CrossRef]

14. Bawazir, A.; Saddiq, A. Antimicrobial activity of date palm (Phoenix dactylifera) pits extracts and its role in reducing the side effect of methyl prednisolone on some neurotransmitter content in the brain, hormone testosterone in adulthood. In Proceedings of the IV International Date Palm Conference 882, Abu Dhabi, United Arab Emirates, 15-17 March 2010; pp. 665-690.

15. Sahyon, H.A.; Al-Harbi, S.A. Antimicrobial, anticancer and antioxidant activities of nano-heart of Phoenix dactylifera tree extract loaded chitosan nanoparticles: In vitro and in vivo study. Int. J. Biol. Macromol. 2020, 160, 1230-1241. [CrossRef] [PubMed]

16. El Abed, H.; Chakroun, M.; Abdelkafi-Koubaa, Z.; Drira, N.; Marrakchi, N.; Mejdoub, H.; Khemakhem, B. Antioxidant, AntiInflammatory, and Antitumoral Effects of Aqueous Ethanolic Extract from (Phoenix dactylifera) L. Parthenocarpic Dates. Biomed Res. Int. 2018, 2018, 1542602. [CrossRef] [PubMed]

17. Rahmani, A.H.; Aly, S.M.; Ali, H.; Babiker, A.Y.; Srikar, S. Therapeutic effects of date fruits (Phoenix dactylifera) in the prevention of diseases via modulation of anti-inflammatory, anti-oxidant and anti-tumour activity. Int. J. Clin. Exp. Med. 2014, 7, 483.

18. Al Juhaimi, F.; Özcan, M.M.; Adiamo, O.Q.; Alsawmahi, O.N.; Ghafoor, K.; Babiker, E.E. Effect of date varieties on physicochemical properties, fatty acid composition, tocopherol contents, and phenolic compounds of some date seed and oils. J. Food Process. Preserv. 2018, 42, e13584. [CrossRef]

19. Idowu, A.T.; Igiehon, O.O.; Adekoya, A.E.; Idowu, S. Dates palm fruits: A review of their nutritional components, bioactivities and functional food applications. Aims Agric. Food 2020, 5, 734. [CrossRef]

20. Djojosubroto, M.W.; Choi, Y.S.; Lee, H.W.; Rudolph, K.L. Telomeres and telomerase in aging, regeneration and cancer. Mol. Cells 2003, 15, 164-175.

21. Elsewedy, H.S.; Al Dhubiab, B.E.; Mahdy, M.A.; Elnahas, H.M. A Review Article on the Basic Concepts of Drug Delivery Systems as Targeting Agents. Int. J. Pharma Med. Biol. Sci. 2021, 10, 23-29.

22. Thiruvengadam, M.; Rajakumar, G.; Chung, I.-M. Nanotechnology: Current uses and future applications in the food industry. 3 Biotech 2018, 8, 74. [CrossRef]

23. Din, F.U.; Aman, W.; Ullah, I.; Qureshi, O.S.; Mustapha, O.; Shafique, S.; Zeb, A. Effective use of nanocarriers as drug delivery systems for the treatment of selected tumors. Int. J. Nanomed. 2017, 12, 7291-7309. [CrossRef] [PubMed]

24. Soliman, W.E.; Shehata, T.M.; Mohamed, M.E.; Younis, N.S.; Elsewedy, H.S. Enhancement of Curcumin Anti-Inflammatory Effect via Formulation into Myrrh Oil-Based Nanoemulgel. Polymers 2021, 13, 577. [CrossRef] [PubMed]

25. Wahgiman, N.A.; Salim, N.; Rahman, M.B.A.; Ashari, S.E. Optimization of nanoemulsion containing gemcitabine and evaluation of its cytotoxicity towards human fetal lung fibroblast (MRC5) and human lung carcinoma (A549) cells. Int. J. Nanomed. 2019, 14, 7323. [CrossRef] [PubMed] 
26. Nayak, A.K.; Ahmed, S.A.; Beg, S.; Tabish, M.; Hasnain, M.S. Chapter 18-Application of Quality by Design for the Development of Biopharmaceuticals. In Pharmaceutical Quality by Design; Beg, S., Hasnain, M.S., Eds.; Academic Press: Cambridge, MA, USA, 2019; pp. 399-411. [CrossRef]

27. Rahman, Z.; Zidan, A.S.; Habib, M.J.; Khan, M.A. Understanding the quality of protein loaded PLGA nanoparticles variability by Plackett-Burman design. Int. J. Pharm. 2010, 389, 186-194. [CrossRef] [PubMed]

28. Li, X.; Wang, L.; Wang, B. Optimization of encapsulation efficiency and average particle size of Hohenbuehelia serotina polysaccharides nanoemulsions using response surface methodology. Food Chem. 2017, 229, 479-486. [CrossRef] [PubMed]

29. Tang, S.Y.; Manickam, S.; Wei, T.K.; Nashiru, B. Formulation development and optimization of a novel Cremophore EL-based nanoemulsion using ultrasound cavitation. Ultrason. Sonochemistry 2012, 19, 330-345. [CrossRef] [PubMed]

30. Benmeddour, Z.; Mehinagic, E.; Le Meurlay, D.; Louaileche, H. Phenolic composition and antioxidant capacities of ten Algerian date (Phoenix dactylifera L.) cultivars: A comparative study. J. Funct. Foods 2013, 5, 346-354. [CrossRef]

31. Oliveira, R.N.; Mancini, M.C.; Oliveira, F.C.S.d.; Passos, T.M.; Quilty, B.; Thiré, R.M.d.S.M.; McGuinness, G.B. FTIR analysis and quantification of phenols and flavonoids of five commercially available plants extracts used in wound healing. Matéria (Rio de Janeiro) 2016, 21, 767-779. [CrossRef]

32. Choudhury, S.R.; Mandal, A.; Chakravorty, D.; Gopal, M.; Goswami, A. Evaluation of physicochemical properties, and antimicrobial efficacy of monoclinic sulfur-nanocolloid. J. Nanoparticle Res. 2013, 15, 1-11. [CrossRef]

33. Thamaraiselvi, J.; Kalpanadevi, S. Determination of some properties of reused cooking ground nut oil using FTIR spectroscopy. Orient. J. Chem. 2012, 28, 1777. [CrossRef]

34. Ibrahim, H.M.; Ahmed, T.A.; Hussain, M.D.; Rahman, Z.; Samy, A.M.; Kaseem, A.A.; Nutan, M.T. Development of meloxicam in situ implant formulation by quality by design principle. Drug Dev. Ind. Pharm. 2014, 40, 66-73. [CrossRef]

35. Sathyamoorthy, N.; Magharla, D.; Chintamaneni, P.; Vankayalu, S. Optimization of paclitaxel loaded poly ( $\varepsilon$-caprolactone) nanoparticles using Box Behnken design. Beni Suef Univ. J. Basic Appl. Sci. 2017, 6, 362-373. [CrossRef]

36. Araújo, F.; Kelmann, R.; Araújo, B.; Finatto, R.; Teixeira, H.; Koester, L. Development and characterization of parenteral nanoemulsions containing thalidomide. Eur. J. Pharm. Sci. 2011, 42, 238-245. [CrossRef]

37. Elsewedy, H.S.; Aldhubiab, B.E.; Mahdy, M.A.; Elnahas, H.M. Brucine PEGylated nanoemulsion: In vitro and in vivo evaluation. Colloids Surf. A Physicochem. Eng. Asp. 2021, 608, 125618. [CrossRef]

38. Harun, S.N.; Nordin, S.A.; Abd Gani, S.S.; Shamsuddin, A.F.; Basri, M.; Basri, H.B. Development of nanoemulsion for efficient brain parenteral delivery of cefuroxime: Designs, characterizations, and pharmacokinetics. Int. J. Nanomed. 2018, $13,2571$. [CrossRef]

39. Danaei, M.; Dehghankhold, M.; Ataei, S.; Hasanzadeh Davarani, F.; Javanmard, R.; Dokhani, A.; Khorasani, S.; Mozafari, M.R. Impact of Particle Size and Polydispersity Index on the Clinical Applications of Lipidic Nanocarrier Systems. Pharmaceutics 2018, 10, 57. [CrossRef]

40. Sarheed, O.; Dibi, M.; Ramesh, K.V. Studies on the Effect of Oil and Surfactant on the Formation of Alginate-Based O/W Lidocaine Nanocarriers Using Nanoemulsion Template. Pharmaceutics 2020, 12, 1223. [CrossRef]

41. Laxmi, M.; Bhardwaj, A.; Mehta, S.; Mehta, A. Development and characterization of nanoemulsion as carrier for the enhancement of bioavailability of artemether. Artif. Cells Nanomed. Biotechnol. 2015, 43, 334-344. [CrossRef]

42. Efentakis, M.; Al-Hmoud, H.; Buckton, G.; Rajan, Z. The influence of surfactants on drug release from a hydrophobic matrix. Int. J. Pharm. 1991, 70, 153-158. [CrossRef]

43. Cabello-Alvarado, C.; Andrade-Guel, M.; Pérez-Alvarez, M.; Cadenas-Pliego, G.; Cortés-Hernández, D.A.; Bartolo-Pérez, P.; Ávila-Orta, C.; Cruz-Delgado, V.; Zepeda-Pedreguera, A. Graphene nanoplatelets modified with amino-groups by ultrasonic radiation of variable frequency for potential adsorption of uremic toxins. Nanomaterials 2019, 9, 1261. [CrossRef]

44. Mehmood, T.; Ahmed, A.; Ahmad, A.; Ahmad, M.S.; Sandhu, M.A. Optimization of mixed surfactants-based $\beta$-carotene nanoemulsions using response surface methodology: An ultrasonic homogenization approach. Food Chem. 2018, 253, 179-184. [CrossRef] [PubMed]

45. Cheng, Y.; Liu, M.; Hu, H.; Liu, D.; Zhou, S. Development, Optimization, and Characterization of PEGylated Nanoemulsion of Prostaglandin E1 for Long Circulation. Aaps Pharmscitech 2016, 17, 409-417. [CrossRef] [PubMed]

46. Suk, J.S.; Xu, Q.; Kim, N.; Hanes, J.; Ensign, L.M. PEGylation as a strategy for improving nanoparticle-based drug and gene delivery. Adv. Drug Del. Rev. 2016, 99, 28-51. [CrossRef] [PubMed]

47. Shehata, T.; Ogawara, K.-i.; Higaki, K.; Kimura, T. Prolongation of residence time of liposome by surface-modification with mixture of hydrophilic polymers. Int. J. Pharm. 2008, 359, 272-279. [CrossRef]

48. Shen, L.; Guo, A.; Zhu, X. Tween surfactants: Adsorption, self-organization, and protein resistance. Surf. Sci. 2011, 605, 494-499. [CrossRef]

49. Buszello, K.; Harnisch, S.; Müller, R.H.; Müller, B.W. The influence of alkali fatty acids on the properties and the stability of parenteral O/W emulsions modified with solutol HS 15. Eur. J. Pharm. Biopharm. 2000, 49, 143-149. [CrossRef]

50. Fredslund, F.; Laursen, N.S.; Roversi, P.; Jenner, L.; Oliveira, C.L.; Pedersen, J.S.; Nunn, M.A.; Lea, S.M.; Discipio, R.; SottrupJensen, L.; et al. Structure of and influence of a tick complement inhibitor on human complement component 5. Nat. Immunol. 2008, 9, 753-760. [CrossRef]

51. Shehata, T.; Kimura, T.; Higaki, K.; Ogawara, K.I. In-vivo disposition characteristics of PEG niosome and its interaction with serum proteins. Int. J. Pharm. 2016, 512, 322-328. [CrossRef] 
52. Tyner, K.M.; Zou, P.; Yang, X.; Zhang, H.; Cruz, C.N.; Lee, S.L. Product quality for nanomaterials: Current US experience and perspective. Wiley Interdiscip. Rev. Nanomed. Nanobiotechnol. 2015, 7, 640-654. [CrossRef] [PubMed]

53. Germain, M.; Caputo, F.; Metcalfe, S.; Tosi, G.; Spring, K.; Åslund, A.K.; Pottier, A.; Schiffelers, R.; Ceccaldi, A.; Schmid, R. Delivering the power of nanomedicine to patients today. J. Control. Release 2020, 326, 164-171. [CrossRef] [PubMed]

54. Murugan, C.; Rayappan, K.; Thangam, R.; Bhanumathi, R.; Shanthi, K.; Vivek, R.; Thirumurugan, R.; Bhattacharyya, A.; Sivasubramanian, S.; Gunasekaran, P.; et al. Combinatorial nanocarrier based drug delivery approach for amalgamation of anti-tumor agents in breast cancer cells: An improved nanomedicine strategy. Sci. Rep. 2016, 6, 34053. [CrossRef]

55. Ma, Y.; Li, Z.; Wang, Y.; Feng, J. Brucine induces the apoptosis of U266 multiple myeloma cells by phosphorylation of c-Jun. Mol. Med. Rep. 2013, 7, 481-484. [CrossRef] [PubMed]

56. Abdel-Wahab, N.M.; Hamed, A.N.; Khalil, H.E.; Samy, M.N.; Wanas, A.S.; Fouad, M.A.; Kamel, M.S. Phenolic acid glycosides from Parmentiera cereifera Seem. (Candle tree). Phytochem. Lett. 2014, 9, 74-77. [CrossRef]

57. El-Halawany, A.M.; Abdallah, H.M.; Hamed, A.R.; Khalil, H.E.; Almohammadi, A.M. Phenolics from Barleria cristata var. Alba as carcinogenesis blockers against menadione cytotoxicity through induction and protection of quinone reductase. BMC Complement. Altern. Med. 2018, 18, 1-7. [CrossRef] [PubMed]

58. Khalil, H.E.; Al Ahmed, A. Phytochemical Analysis and Free Radical Scavenging Activity of Carthamus oxyacantha growing in Saudi Arabia: A Comparative Study. Int. J. Pharm. Sci. Rev. Res. 2017, 45, 51-55.

59. Khalil, H.E.; Aljeshi, Y.M.; Saleh, F.A.; Mohamed, T.S. Assessment of chemical composition and the antimicrobial and antioxidant activities of Bassia eriophora growing in Eastern province of Saudi Arabia. JOCPR 2017, 9, 210-215.

60. Soliman, W.E.; Khan, S.; Rizvi, S.M.D.; Moin, A.; Elsewedy, H.S.; Abulila, A.S.; Shehata, T.M. Therapeutic Applications of Biostable Silver Nanoparticles Synthesized Using Peel Extract of Benincasa hispida: Antibacterial and Anticancer Activities. Nanomaterials 2020, 10, 1954. [CrossRef]

61. Shehata, T.M.; Nair, A.B.; Al-Dhubiab, B.E.; Shah, J.; Jacob, S.; Alhaider, I.A.; Attimarad, M.; Elsewedy, H.S.; Ibrahim, M.M. Vesicular Emulgel Based System for Transdermal Delivery of Insulin: Factorial Design and in Vivo Evaluation. Appl. Sci. 2020, 10, 5341. [CrossRef]

62. Shah, J.; Nair, A.B.; Shah, H.; Jacob, S.; Shehata, T.M.; Morsy, M.A. Enhancement in antinociceptive and anti-inflammatory effects of tramadol by transdermal proniosome gel. Asian J. Pharm. Sci. 2020, 15, 786-796. [CrossRef]

63. Uchegbu, I.F.; Duncan, R. Niosomes containing N-(2-hydroxypropyl) methacrylamide copolymer-doxorubicin (PK1): Effect of method of preparation and choice of surfactant on niosome characteristics and a preliminary study of body distribution. Int. J. Pharm. 1997, 155, 7-17. [CrossRef]

64. Xu, M.-R.; Wei, P.-F.; Suo, M.-Z.; Hu, Y.; Ding, W.; Su, L.; Zhu, Y.-D.; Song, W.-J.; Tang, G.-H.; Zhang, M.; et al. Brucine Suppresses Vasculogenic Mimicry in Human Triple-Negative Breast Cancer Cell Line MDA-MB-231. Biomed. Res. Int. 2019, $2019,6543230$. [CrossRef] [PubMed]

65. Khalil, H.E.; Mohamed, M.E.; Morsy, M.A.; Kandeel, M. Flavonoid and phenolic compounds from Carissa macrocarpa: Molecular docking and cytotoxicity studies. Pharmacogn. Mag. 2018, 14, 304. [CrossRef]

66. Deng, X.; Yin, F.; Lu, X.; Cai, B.; Yin, W. The Apoptotic Effect of Brucine from the Seed of Strychnos nux-vomica on Human Hepatoma Cells is Mediated via Bcl-2 and $\mathrm{Ca}^{2+}$ Involved Mitochondrial Pathway. Toxicol. Sci. 2006, 91, 59-69. [CrossRef] [PubMed] 